Jurnal Kesehatan Perintis (Perintis's Health Journal) 8 (1) 2021: 67-74

Contents list available at JKP website

Jurnal Kesehatan Perintis (Perintis's Health Journal)

Journal homepage: https://jurnal.stikesperintis.ac.id/index.php/JKP

\title{
Uji Daya Hambat Dan Daya Bunuh Ekstrak Buah Mengkudu (Morinda Citrifolia Linn) Terhadap Pertumbuhan Bakteri Staphylococcus Aureus
}

\section{Dyna Putri Mayaserli, Dewi Yudiana Shinta}

\author{
Progam Studi D-III Teknologi Laboratorium Medik, Universitas Perintis Indonesia, \\ Sumatera Barat, Indonesia
}

Article Information :

Submission: May 05, 2021; Revised:Jun 26, 2021; Accepted:Jun 30, 2021; Available online: Jun 30,2021

*Corresponding author : dyna2205@yahoo.com

\begin{abstract}
ABSTRAK
Mengkudu (Morinda citrifolia Linn.) memiliki kandungan antrakuinon yang terbukti mempunyai efek farmakologik sebagai lisosim terhadap sel bakteri Mengkudu (Morinda citrifolia Linn) merupakan salah satu tanaman obat yang banyak digunakan masyarakat sebagai obat tradisional. Mengkudu diketahui memiliki zat aktif yang terkandung didalamnya seperti flavonoid, tannin, filantin, sebagai antioksidan dan antibakteri. Staphylococcus aureus merupakan gram positif dan sebagai bakteri penyebab diare, bakteri ini bisa berada pada saluran cerna. Penelitian ini bertujuan untuk Mengetahui konsentrasi efektif ekstrak mengkudu (Morinda citrifolia Linn) terhadap bakteri Staphylococcus aureus. Manfaat penelitian ini untuk untuk mengetahui efektifitas ekstrak buah mengkudu terhadap bakteri Staphylococcus aureus. Penelitian ini merupakan penelitian eksperimental laboratorium dengan menggunakan metode difusi cakram Kirby-Bauer untuk mengetahui diameter zona hambat dan zona bunuh bakteri Staphylococcus aureus, konsentrasi ekstrak mengkudu yang digunakan $25 \mathrm{mg}, 50 \mathrm{mg}, 75 \mathrm{mg}, 100 \mathrm{mg}$, dan ciprofloxacin sebagai control positif sedangkan aquadest sebagai kontrol negatif. Dari hasil penelitian didapatkan bahwa konsentrasi $75 \mathrm{mg}$ - $100 \mathrm{mg}$ mampu membunuh bakteri Staphylococcus aureus dengan zona bunuh yang terbentuk $>20 \mathrm{~mm}$. Hasil penelitian, semakin tinggi konsentrasi ekstrak, semakin besar pula diameter daya hambat dan daya bunuh yang terbentuk. Ekstrak buah mengkudu mampu membunuh pertumbuhan bakteri Staphylococcus aureus dengan daya bunuh lebih besar dari antibiotik kontrol posistif dan efektif digunakan sebagai obat antibakteri yang tidak resisten.
\end{abstract}

Kata kunci : Staphylococcus aureus, Kirby bauer. Mengkudu (Morinda citrifolia Linn)

\section{ABSTRACT}

Noni (Morinda citrifolia Linn.) contains anthraquinone which is proven to have a pharmacological effect as lysozyme against bacterial cells. Noni (Morinda citrifolia Linn.) is one of the medicinal plants that is widely used by the community as traditional medicine. Noni is known to have active substances contained in it such as flavonoids, tannins, phyllantins, as antioxidants and antibacterials. Staphylococcus aureus is gram positive and as a bacteria that causes diarrhea, this bacteria can be in the gastrointestinal tract. This study aims to determine the effective concentration of noni extract (Morinda citrifolia Linn) 
against Staphylococcus aureus bacteria. The benefit of this study was to determine the effectiveness of noni fruit extract against Staphylococcus aureus bacteria. This study is a laboratory experimental study using the Kirby-Bauer disc diffusion method to determine the diameter of the inhibition zone and the killing zone of Staphylococcus aureus bacteria, the concentration of noni extract used $25 \mathrm{mg}, 50 \mathrm{mg}, 75 \mathrm{mg}, 100 \mathrm{mg}$, and ciprofloxacin as a positive control while aquadest was used as a control. negative control. From the results of the study, it was found that a concentration of $75 \mathrm{mg}-100 \mathrm{mg}$ was able to kill Staphylococcus aureus bacteria with a killing zone formed $>20 \mathrm{~mm}$. The results of the study, the higher the concentration of the extract, the greater the diameter of the inhibition and killing power formed. Noni fruit extract was able to kill the growth of Staphylococcus aureus bacteria with greater killing power than positive control antibiotics and was effectively used as non-resistant antibacterial drugs.

Keyword: Staphylococcus aureus, kirby bauer. Noni (Morinda citrifolia Linn)

\section{PENDAHULUAN}

Penggunaan tumbuhan dan bahan alami sebagai antimikroba merupakan alternatif yang dapat dilakukan oleh masyarakat, karena semakin banyaknya resistensi yang terjadi pada obat-obatan kimia. Saat ini di masyarakat angka kejadian infeksi masih tinggi dan masih banyak infeksi tersebut dikarenakan oleh infeksi bakteri. Salah satu bakteri penyebab adalah Staphylococcus sp. Staphylococcus aureus adalah jenis bakteri patogen yang dapat menimbulkan infeksi dan kelainan pada kulit (Andri DH, 2011). Bakteri ini juga menimbulkan penyakit - penyakit seperti keracunan makan, supurasi, pembentukan abses, infeksi piogenik, septikemia, dan infeksi kulit yang sering disebut pioderma (Amaliyah, N, 2020)

Kebutuhan akan antibakteri sangat besar sebagai pengobatan penyakit infeksi. Penyakit infeksi merupakan jenis penyakit yang paling banyak diderita oleh penduduk di negara berkembang, termasuk Indonesia. Salah satu penyebab dari penyakit infeksi adalah bakteri. Bakteri yang menyebabkan penyakit infeksi merupakan bakteri gram positif dan gram negatif masih merupakan masalah yang sulit diatasi karena menyangkut kesadaran masyarakat terhadap kebersihan dan kesehatan (Simatupang, 2017)

Salah satu tanaman yang mempunyai potensi obat yaitu buah mengkudu (Morinda citifolia L) mempunyai 150 kandungan fitonutrien didalamnya. Fitonutrien merupakan senyawa tambahan yang berfungsi sebagai antivirus, anti inflamasi dan anti bakteri (Hardani et al., 2020). Fitonutrien dapat juga meningkatkan daya tahan tubuh dan memperbaiki sel-sel di dalam tubuh. Mengkudu (Morinda citrifolia) dipercaya mempunyai efek analgesik dalam tubuh, yang artinya tubuh akan mendapatkan kekebalan terhadap berbagai macam penyakit termasuk kanker. Kandungan yang lain adalah vitamin A, B kompleks, C, sulfur, kalium, fosfor, asam amino dan kalsium (Bhore \& Sathisha, 2010)

Pemanfaatan mengkudu sebagai obat dan sayuran dipergunakan untuk mengobati berbagai penyakit seperti tumor, luka, penyakit kulit, gangguan pernafasan (asma), demam, diare dan penyakit usia lanjut. Masyarakat di Amerika Tengah juga menyebut mengkudu sebagai pain killer tree karena diketahui bahwa sari buah mengkudu berfungsi sebagai adaptogen yang dapat menyeimbangkan fungsi sel-sel dan juga menormalkan fungsi otak tempat pengendalian rasa sakit (Astuti W, 2016)

Kandungan kimia daun mengkudu, berupa saponin, flavonoid, polifenol, tanin, dan terpenoid memiliki efek sebagai anti bakteri. Senyawa kimia tersebut telah dibuktikan memilik akitivitas sebagai anti bakteri pada Bacillus subtilis, Bacillus cereus, Pseudomonas aerugenosa, dan Staphylococcus aureus (Kelemu et al., 2011). Berdasarkan hasil penelitian yang dilakukan diperoleh hasil ekstrak daun mengkudu (Morinda citrifolia L.) terbukti memiliki efek antibakteri pada Staphylococcus epidermidis dengan diameter zona hambat yang meningkat setiap konsentrasi (Kelemu et al., 2011).

Hasil penelitian Astuti,W,2016, juga melakukan uji antibakteri daun mengkudu terhadap Staphylococcus aureus yang 
dapat menghambat pertumbuhan bakteri tersebut dengan konsentrasi $75 \%$ yang melebihi konsentrasi kontrol positif (Marquez-Santacruz et al., 2010). Perbedaan dengan penelitain yang dilakukan sekarang dimana penelitian ini juga melihat daya kemampuan daya bunuh dari buah ekstrak buah mengkudu karena yang diharapkan dari suatu antibakteri adalah mampu membunuh dari bakteri tersebut dan tidak menimbulkan resistensi. Selain itu pada penelitian menggunakan ciprofloxacin yang belum resistensi sebagai kontrol positif. Berbeda dengan penelitianpenelitian lain yang menggunakan Amoxicilin dan Vankomisin sebagai kontol positifnya (Galuh, Puspitasari, 2012)

Penelitian ini bertujuan untuk mengetahui konsentrasi efektif ekstrak mengkudu (Morinda citrifolia Linn) terhadap bakteri Staphylococcus aureus baik secara daya hambat maupun daya bunuh (Simatupang, 2017). Manfaat penelitian ini untuk untuk mengetahui efektifitas ekstrak buah mengkudu terhadap bakteri Staphylococcus aureus. Ekstrak buah mengkudu mampu membunuh pertumbuhan bakteri Staphylococcus aureus dengan daya bunuh lebih besar dari antibiotik kontrol posistif dan efektif digunakan sebagai obat antibakteri yang tidak resisten.

\section{METODE PENELITIAN}

Penelitian ini merupakan penelitian eksperimental laboratorium dengan menggunakan metode difusi cakram KirbyBauer untuk mengetahui diameter zona hambat dan zona bunuh bakteri Staphylococcus aureus, konsentrasi ekstrak mengkudu yang digunakan $25 \mathrm{mg}$, $50 \mathrm{mg}, 75 \mathrm{mg}, 100 \mathrm{mg}$, dan ciprofloxacin sebagai control positif sedangkan aquadest sebagai kontrol negatif.

\section{Alat dan Bahan}

Alat yang digunakan dalam penelitian ini yaitu cawan petri, inkubator, blender, rotary evaporator, pipet tetes, beaker glass, autoclove, lampu spiritus, tabung reaksi, rak tabung, mistar, labu erlemeyer, timbangan digital, gelas ukur, pengaduk, oven, laminar air flow dan gelas arloji. Bahan yang digunakan dalam penelitian ini adalah : strain murni bakteri
Staphylococcus aureus, ekstrak etanol buah mengkudu (Morinda citrifilia Linn), $\mathrm{NaCl}$ fisiologis steril (dalam kemasan), disk kosong steril, aquades, kertas saring, antibiotik Ciprofloxasin HA (Muller Hilton Agar), NB (Nutrient Broth), Endo Agar, Nutrient Agar, dan Larutan Mc Farland.

\section{Pembuatan Media Mueller Hinton Agar (MHA)}

Media $\mathrm{MH}$ dibuat dengan melarutkan 38 gram $\mathrm{MH}$ agar dalam 1 liter aquadest dengan komposisi, bee ektrak powder 2 gram, acid digest of casein 17,5 gram, starch 1,5 gram,bacto agar 1,7 gram. Panaskan hingga larut dengan sempurna, sterilisasipada autoclave pada suhu $121^{\circ} \mathrm{C}$ selama 15 menit dengan tekanan $1 \mathrm{~atm}$, biarkan dingin pada suhu kurang lebih $50^{\circ} \mathrm{C}$ dengan $\mathrm{pH}$ 7,4 kemudian masukkan dalam Petridis steril kira-kira 10-20 mg tebal 3-4 $\mathrm{mm}$.

\section{Media Cair NB}

Sebanyak 12 gram media NB (Nutrient Broth) ditambah aquades sampai $100 \mathrm{ml}$, kemudian dipanaskan sampai semua bahan larut dengan sempurna,setelah itu media disterilkan dalam autoclave pada suhu $121^{\circ} \mathrm{C}$ selama 15 menit.

\section{Pembuatan Larutan Mc Farland}

Pipet larutan $\mathrm{H}_{2} \mathrm{SO}_{4} 1 \%$ sebanyak 9,5 $\mathrm{ml}$, masukkan dalam tabung reaksi.

Tambahkan larutan $\mathrm{BaCl}_{2} \quad 1 \%$ dan sebanyak $0,5 \mathrm{ml}$ kedalam tabung yang berisi $\mathrm{H}_{2} \mathrm{SO}_{4} 1 \%$, setelah itu homogenkan dimana suspensi Mc. Farlandadalah suspensi standar yang mununjukkan kekeruhan sama dengan $10^{8} \mathrm{CFU} / \mathrm{ml}$ (Soemarno, 2000).

\section{Cakram (Disk)}

Cakram yang digunakan adalah cakram yang berdiameter $6 \mathrm{~mm}$ yang sudah jadi dan steril.

\section{Pembuatan Ekstrak Buah Mengkudu Penyiapan Simplisia}

Simplisia adalah bahan alam atau tumbuhan yang telah dikeringkan dengan suhu pengeringan simplisia tidak lebih dari $60^{\circ} \mathrm{C}$ (Anonim, 2009). Pengambilan sampel buah mengkudu (Morinda citrofilia Linn) dilakukan dengan golok dan dipilih tumbuhan yang segar dan masih dalam 
keadaan baik. Kemudian buah mengkudu (Morinda citrifilia Linn.) disortasi basah dan dikupas kulit daunya, kemudian ditimbang dan selanjutnya diteruskan dengan metode maserasi ekstraksi.

\section{Pembuatan Ekstrak}

Pembuatan Ekstrak Metode ekstraksi yang digunakan untuk mengekstraksi tumbuhan buah mengkudu (Morinda citrifilia Linn) adalah memakai metode ekstraksi cara dingin yakni maserasi.

\section{Pembuatan Ekstrak Buah Mengkudu (Morinda citrifilia Linn)}

Buah mengkudu dikupas dahulu sehingga mendapatkan daging buah mengkudu sebanyak 500 gram dihaluskan dengan blender kemudian direndam dengan $1000 \mathrm{ml}$ pelarut etanol $70 \%$, setelah itu didiamkan selama 2-3 hari dalam toples tertutup. Maserat dituang dan diperas. Ampas dimaserasi lagi dengan cairan pelarut yang baru sampai terendam. Remaserasi dilakukan sebanyak 3 kali maserasi, lalu hasil maserat di evaporasi pada rotary evaporator hingga diperoleh ektrak kental buah mengkudu yang kemudian untuk mengetahui beratnya.

\section{Prosedur Kerja}

\section{Pembuatan Konsentrasi Buah Menegkudu (Morinda citrifilia Linn):}

Konsentrasi $25 \mathrm{mg} / \mathrm{ml}: 0,25 \mathrm{gr}$ ekstrak buah mengkudu tambahkan aquadest $1 \mathrm{ml}$. Konsentrasi $50 \mathrm{mg} / \mathrm{ml}: 0,50 \mathrm{gr}$ ekstrak buah mengkudu tambahkan aquadest $1 \mathrm{ml}$. Konsentrasi $75 \mathrm{mg} / \mathrm{ml}: 0,75 \mathrm{gr}$ ekstrak buah mengkudu tambahkan aquadest $1 \mathrm{ml}$. Konsentrasi $100 \mathrm{mg} / \mathrm{ml}: 1 \mathrm{gr}$ ekstrak buah mengkudu tanpa penambahan.

\section{Pembuatan Suspensi Bakteri}

Bakteri biakan Staphylococcus aureus dibuat suspensi dengan menambahkan larutan Nutrient Broth (NB) di dalam tabung reaksi, sampai didapatkan kekeruhan yang disesuaikan dengan standar kekeruhan Mc. Farland 0,5 untuk mendapatkan bakteri 1,5 x $10^{8} \mathrm{CFU} / \mathrm{mL}$ (Soemarno, 2000).

\section{Penanaman Pada Media MHA}

Dicelupkan kapas lidi steril kedalam suspensi bakteri yang sudah distandarisasi kekeruhannya, tunggu sampai meresap kedalam kapas. Kapas lidi diangkat dengan menekan pada dinding tabung ( $\mathrm{Mj}$ et al., 2011). Goreskan kapas lidi tersebut pada Media Muller Hinton Agar Plate dengan memutar cawan petridishsampaimerata kesemua permukaan media. Biarkan selama 5 sampai 15 menit, supaya suspensi bakteri meresap kedalam agar (Yan, 2011)

\section{Pembacaan Daya Hambat dan Daya Bunuh}

Pengamatan dilakukan setelah biakan diinkubasi selama 24 - 72 jam, setiap $1 \times 24$ jam biakan dicek dan diamati zona bening yang terbentuk disekitar kertas cakram yang berisi sampel ekstrak buah mengkudu (Morinda citrofilia Linn) (Ravikumar et al., 2011). Bandingkan zona bening yang terbentuk setiap harinya sampai zona bening memiliki angka yang sama atau tidak ada lagi perbandingan dengan hari sebelumnya. Kemudian dibandingkan apakah ekstrak buah mengkudu dapat membunuh bakteri Staphylococcus aureus atau hanya menghambat pertumbuhanya saja. Pengukuran zona bening dilakukan dengan menggunakan mistar melalui tiga daerah pengukuran pada bidang zona yang berbeda kemudian mencari rata ratanya untuk medapatkan diameter zona bebas bakteri (Yang et al., 2011)

\section{Uji Aktivitas Bakteri Terhadap Antibiotik \\ Bakteri diambil dari suspensi yang} telah disetarakan dengan standarMcFarland (108 CFU/mL) sebanyak $300 \mu \mathrm{L}$. Bakteri tersebut diletakkan pada media $\mathrm{MH}$ padat kemudian diratakan dengan spreader glass, setelah itu dibiarkan sampai permukaan kering. Kombinasi dengan volume pengambilan yang telah ditentukan dan kontrol yang digunakan diteteskan pada disk kosong kemudian ditunggu selama 5 menit. Disk yang telah berisi kombinasi ekstrak serta kontrol tersebut diletakkan di atas media yang telah disemai bakteri. Media diinkubasi selama 24-72 jam pada suhu $37^{\circ} \mathrm{C}$ kemudian diamati zona hambat dan bunuhnya (Yan et al., 2011)

\section{Uji Kepekaan Bakteri}

Pelaksanaan uji aktivitas antibakteri ini menggunakan metode difusi cakraam 
Kirby Bauer. Menurut European Committee on Antimicrobial Suspectibility Testing (2012), uji ini menggunakan media MHA dengan kedalaman $3,5 \mathrm{~mm}-4,5 \mathrm{~mm}(25$ $\mathrm{ml}$ media MHA untuk cawan petri berukuran $90 \mathrm{~mm}$ dan $70 \mathrm{ml}$ untuk cawan petri berukuran $150 \mathrm{~mm}$ ). permukaan media harus kering sebelum digunakan Media disimpaan pada suhu $4-8^{\circ} \mathrm{C}$.

Biakan murni dari Staphylococcus aureus yang telah dibiakan sebelumnya dalam media NA selama 24 jam diambil satu koloni dengan menggunakan ose bulat steril. Inoculum tersebut disuspensikan dengan aquades atau $\mathrm{NaCl} 0,9 \%$ dengan menyentuhkan sedikit demi sedikit pada dinding tabung reaksi sehingga diperoleh suspense kuman, lalu divorteks agar inoculum dapat tersuspensi dengan baik. Kerapatan kuman diukur dengan menggunakan spektofotometer pada panjang gelombang $625 \mathrm{~nm}$ dan absobansi 0,08 sampai 0,1 (European Committee on Antimicrobial Susceptibility Testing, 2012). Kapas lidi sterildicelupkan ke dalam suspense kuman, lalu diswab sebanyak tiga kali putaran (sebesar $60^{\circ}$ ) secara merata pada permukaan media MHA. Kertas cakram direndam dalam ekstrak etanol buah mengkudu dengan berbagai varian konsentrasi $(25 \mathrm{mg} / \mathrm{ml}, 50 \mathrm{mg} / \mathrm{ml}, 75$ $\mathrm{mg} / \mathrm{ml}, 100 \mathrm{mg} / \mathrm{ml}$ ) diletakkan di atas media. Control negative berupa cakram yang telah direndam dengan Aquades juga diletakkan diletakkan di atas media. Inkubasikan pada suhu $37^{\circ} \mathrm{C}$ selama $24-72$ jam dan diamati pertumbuhan bakteri dengan zona hambat dan bunuh tertentu. Diameter zona hambat dan bunuh yang terbentuk diukur dengan menggunakan jangka sorong dalam satuan millimeter (mm) (Maizura, M.; Aminah, A.; Wan Aida, 2011)

Suspensi bakteri diambil dan ditanam pada media $\mathrm{MH}$ dengan lidi kapas steril, kemudian biarkan selama 15 menit. Tempelkan cifrolaxasin pada media $\mathrm{MH}$ tersebut sebagai positif Control. Diambil Cakram yang telah direndam ekstrak, tunggu sampai ekstrak daun kumis kucing tidak menetes lagi dari cakram kemudian letakkan cakram diatas media $\mathrm{MH}$, dan diinkubasi pada suhu $37^{\circ} \mathrm{C}$ selama $24-72$ jam. Hambatan bunuh pertumbuhan bakteri dapat ditentukan dengan mengukur diameter daerah bening tanpa pertumbuhan mikroba sekitar cakram dengan menggunakan mistar.

\section{HASIL DAN PEMBAHASAN}

Dari hasil ini didapatkan bahwa ektrak buah mengkudu dapat membunuh pertumbuhan bakteri Staphylococcus aureus pada konsentrasi ekstrak $75 \mathrm{mg}$ $100 \mathrm{mg}$. Hal ini dibuktikan dengan terbentuknya diameter zona bening disekitar cakram yang mengandung ekstrak mengkudu setelah diinkubasi selama 24-72 jam / 2-3 hari. Setelah dilakukan tiga kali pengulangan bahwa ekstrak dengan konsentrasi $75 \mathrm{mg}$ - 100mg memiliki zona bunuh $>20 \mathrm{~mm}$. Berdasarkan tabel klasifikasi zona bunuh bakteri menurut Greenwood, 2006 dalam Salma Abdul, 2014 bahwa diameter zona bening atau zona bunuh $>20 \mathrm{~mm}$ memiliki daya yang kuat.

\section{Uji Daya Hambat dan Daya Bunuh Ekstrak Buah Mengkudu Terhadap Pertumbuhan Bakteri Staphylococcus aureus}

Uji bakteri ini dilakukan dengan menggunakan metode Kirby bauer yang memiliki prinsip berdasarkan pengamatan luas daerah hambatan pertumbuhan bakteri. Penelitian ini menggunakan beberapa konsentrasi Mengkudu (Morinda citrifilia Linn) yaitu $25 \mathrm{mg}, 50 \mathrm{mg}, 75 \mathrm{mg}$ dan $100 \mathrm{mg}$, kemudian kontrol positif menggunakan ciprofilaxin, dan control negatif yaitu aquades steril. Masing-masing dilakukan 3 kali pengulangan Hasil uji Konsentrasi Hambat Maksimal dan Konsentrasi Bunuh Maksimal ekstrak buah (Morinda citrofilia Linn) mengkudu memperlihatkan adanya kenaikan jumlah koloni dari setiap peningkatan konsentrasi ekstrak mengkudu (tabel 1). Data hasil uji daya hambat dan bunuh ekstrak buah mengkudu terhadap pertumbuhan bakteri Staphylococcus aureus dapat dilihat pada tabel 2 dan grafik 1.

Penelitian yang telah dilakukan mengenai efek antibakteri ekstrak mengkudu terhadap pertumbuhan bakteri Staphylococcus aureus didapatakan hasil bahwa ekstrak mengkudu mempunyai efek antibakteri terhadap Staphylococcus aureus. 
Tabel 1 Hasil uji identifikasi ekstrak buah mengkudu terhadap bakteri Staphylococcus aureus

\begin{tabular}{|c|c|c|c|c|}
\hline \multirow{2}{*}{$\begin{array}{l}\text { Kosentrasi } \\
(\mathrm{mg} / \mathrm{ml})\end{array}$} & \multicolumn{3}{|c|}{ Pengulangan } & \multirow{2}{*}{ P.Sig } \\
\hline & 1 & 2 & 3 & \\
\hline 25 & $17,00 \pm 1,52 \mathrm{~mm}$ & $16,00 \pm 1,52 \mathrm{~mm}$ & $14,00 \pm 1,52 \mathrm{~mm}$ & \multirow{4}{*}{0,38} \\
\hline 50 & $20,00 \pm 1,15 \mathrm{~mm}$ & $18,00 \pm 1,15 \mathrm{~mm}$ & $18,00 \pm 1,15 \mathrm{~mm}$ & \\
\hline 75 & $24,00 \pm 1,15 \mathrm{~m}$ & $22,00 \pm 1,15 \mathrm{~mm}$ & $22,00 \pm 1,15 \mathrm{~mm}$ & \\
\hline 100 & $28,00 \pm 0,57 \mathrm{~mm}$ & $27,00 \pm 0,57 \mathrm{~mm}$ & $27,00 \pm 0,57 \mathrm{~mm}$ & \\
\hline Kontrol & & & & \\
\hline Ciprofloxasin & $35,00 \pm 0,57 \mathrm{~mm}$ & $36,00 \pm 0,57 \mathrm{~mm}$ & $36,00 \pm 0,57 \mathrm{~mm}$ & \\
\hline
\end{tabular}

Tabel 2 Hasil diameter zona bunuh yang terbentuk

\begin{tabular}{|c|c|c|c|c|c|c|c|c|c|c|c|c|c|c|c|c|c|c|}
\hline \multirow{3}{*}{ Hari } & \multicolumn{18}{|c|}{ Diameter zona hambat dan bunuh } \\
\hline & \multicolumn{3}{|c|}{ kontrol - aquades } & \multicolumn{3}{|c|}{$25 \mathrm{mg}$} & \multicolumn{3}{|c|}{$50 \mathrm{mg}$} & \multicolumn{3}{|c|}{$75 \mathrm{mg}$} & \multicolumn{3}{|c|}{$100 \mathrm{mg}$} & \multicolumn{3}{|c|}{ Kontrol + cifrolaxasin } \\
\hline & 1 & 2 & 3 & 1 & 2 & 3 & 1 & 2 & 3 & 1 & 2 & 3 & 1 & 2 & 3 & 1 & 2 & 3 \\
\hline 1 & \multicolumn{3}{|c|}{ tidak ada tidak ada tidak ada } & 17 & 16 & 14 & 20 & 18 & 18 & 24 & 22 & 22 & 28 & 27 & 27 & 35 & 36 & 36 \\
\hline 2 & \multicolumn{3}{|c|}{ tidak ada tidak ada tidak ada } & 17 & 16 & 14 & 20 & 18 & 18 & 24 & 22 & 21 & 28 & 27 & 27 & 35 & 35 & 35 \\
\hline 3 & \multicolumn{3}{|c|}{ tidak ada tidak ada tidak ada } & 16 & 15 & 15 & 19 & 17 & 17 & 22 & 20 & 20 & 26 & 26 & 26 & 34 & 34 & 34 \\
\hline \multicolumn{4}{|c|}{ rata-ra } & 16,67 & 15,67 & 14,33 & 19,7 & 18 & 18 & 24 & 22 & 21,33 & 28 & 27 & 27 & 35 & $\mathbf{3 5 , 3 3}$ & 35,33 \\
\hline \multicolumn{4}{|l|}{ SD } & 0,577 & 0,577 & 0,577 & 0,58 & 0,58 & 0,577 & 1,15 & 1,155 & 1 & 1,15 & 0,577 & 0,577 & 0,58 & 1 & 1 \\
\hline
\end{tabular}

Hal ini terbukti dengan terdapatnya diameter zona bunuh yang kuat yaitu $>20$ $\mathrm{mm}$ pada cakram dengan konsentrasi rebusan $75 \mathrm{mg}-100 \mathrm{mg}$. Parameter untuk menilai efektifitas ekstrak mengkudu terhadap bakteri Staphylococcus aureus dilihat melalui diameter zona penghambatan ekstrak. Menurut Astuti,W, 2020 bakteri Staphylococcus aureus dapat mempertahankan zat warna kristal violet sewaktu proses pewarnaan Gram dan bentuk selnya adalah kokus.

Pada penelitian sebelumnya yang digunakan oleh Amaliyah,N (2019) memperlihatkan adanya daya hambat ekstrak buah mengkudu (Morinda citrofilia Linn) terhadap pertumbuhan bakteri Staphylococcus aureus mulai dari $25 \%$ sampai dengan konsentrasi $100 \%$. Hal ini menunjukkan bahwa ekstrakmengkudu dapatmempengaruhi pertumbuhan Staphylococcus aureus. KHM dan KBM ini diuji untuk menentukan berapa besarkah kemampuan suatu zat aktif mampu menghambat pertumbuhan Staphylococcus aureus yang kemampuannya dalam membunuh hampir sama dengan kemampuan obat antibiotic.
Konsentasi terkecil terjadinya penurunan pertumbuhan koloni adalah pada konsentrasi $25 \mathrm{mg}$. Hasil tersebut menunjukan bahwa KHM dari ekstrak mengkudu adalah $25 \mathrm{mg}$, sementara itu pada konsentrasi $100 \mathrm{mg}$ dari ekstrak mengkudu tidak ditemukan pertumbuhan bakteri Staphylococcus aureus yang berarti bahwa KBM adalah $100 \mathrm{mg}$. hasil penelitian yang didapat sesuai dengan penelitian yang dilakukan oleh Djumarang,R,2017 bahwa semakin tinggi konsentasi yang digunakan maka semakin baik dalam menghambat mikroorganisme.

Perbedaan jenis memgkudu mempengaruhi daya hambat dan bunuh mengkudu terhadap bakteri. Jenis mengkudu sangat menentukan jumlah kandungan zat antibakteri yang terkandung di dalam mengkudu tersebut. Adanya variasi biologis dari masing - masing mengkudu mempengaruhi jumlah bahan aktif antimikroba. Mengkudu yang tumbuh di daerah $X$ dapat memiliki kandungan yang berbeda dengan mengkudu yang tumbuh di daerah Y. 


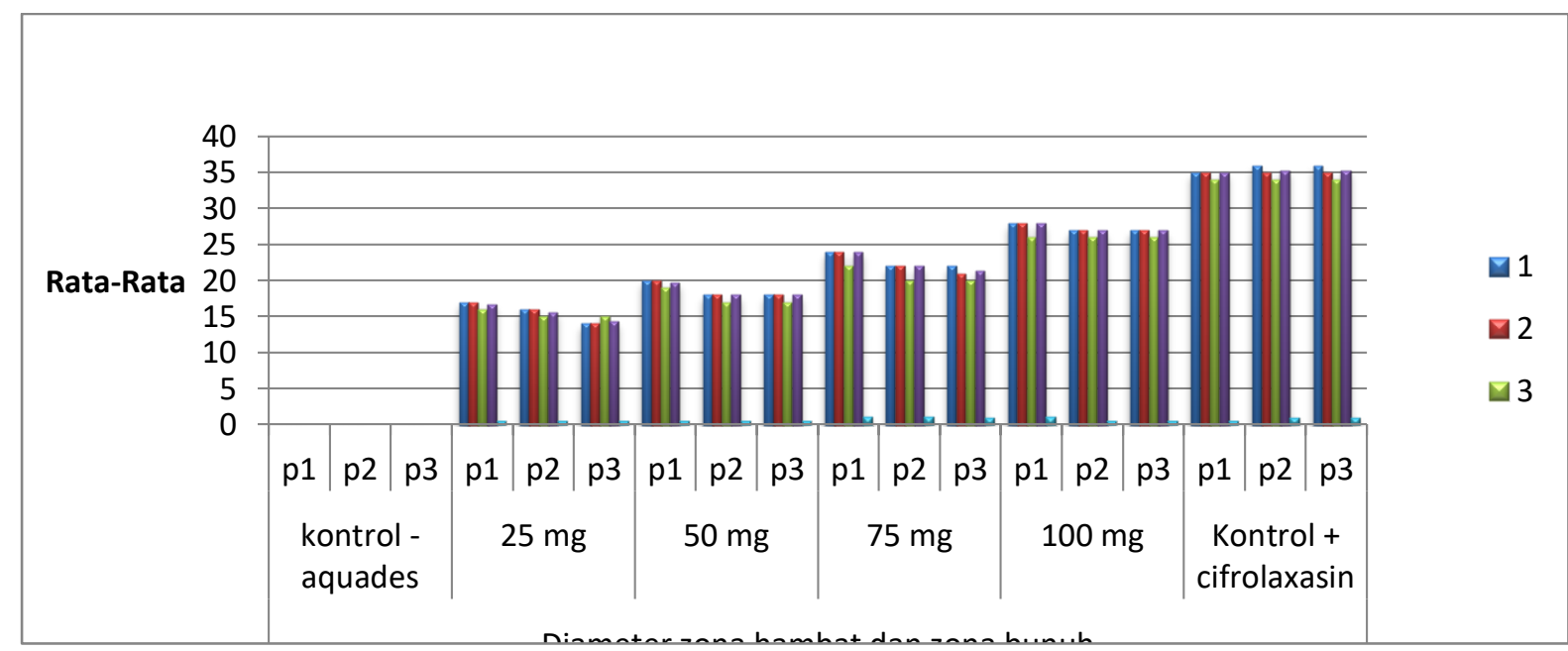

\section{Grafik 1. Hasil pengukuran daya hambat dan daya bunuh dari ekstrak buah mengkudu}

Penelitian ini menggunakan whole decoction yaitu ekstrak mengkudu dari buah yang utuh tanpa memisahkan setiap bagian buah. Bakteri Staphylococcus aureus merupakan bakteri gram positif yang memiliki membran tunggal yang dilapisi peptidoglikan yang lebih kompleks dibandingkan bakteri gram negatif (Sadananda et al., 2011)

Penelitian Tausil,A, 2016 menyimpulkan bahwa ekstrak mengkudu dengan konsentrasi semakin tinggi membentuk zona hambat yang semakin besar dan semakin pekat konsentrasi ekstrak mengkudu, maka senyawa metabolit sekunder yang terdapat di dalam ekstrak tersebut semakin banyak sehingga memberi pengaruh terhadap diameter zona hambat yang terbentuk.

Hasil penelitian ini sama dengan penelitian yang dilakukan oleh Hardani, $R$, 2020 menyatakan kandungan senyawa fenol pada buah mengkudu merupakan antibakteri tertinggi yang dapat menghambat pertumbuhan bakteri Staphylococcus aureus. Penghambatan ekstrak uji pada penelitian dapat dipengaruhi oleh senyawa-senyawa yang terkandung yaitu proxeronin, xeronin, flavonoid, dan fenol. Selain itu, buah mengkudu mengandung scopoletin sebagai analgesic, glikosida sebagai imunostimulan dan proxeronin, xeronin, flavonoid sebagai antibakteri, tetapi fenol sebagai antibakteri tertinggi yang terdapat pada ekstrak mengkudu.

Buah mengkudu mempunyai khasiat antibakteri karena buah mengkudu mengandung bahan aktif scopoletin, ascorbic acid, beta carotene, I-arginine, dan proxeronine. Enzim proxeronase dan alkaloid proxeronine, kedua zat ini akan membentuk zat aktif bernama xeronine di dalam tubuh. Xeronine adalah komponen essensial dalam protein membran sel. Setiap sel mempunyai membran yang terdiri dari lapisan protein peptida. Peptidapeptida ini dirangkaikan dengan ikatan, ikatan tersebut akan menjadi lemah tanpa peran dari alkaloid xeronine. Enzim inilah yang dapat menekan pertumbuhan bakteri, salah satunya bakteri Staphylococcus aureus.

\section{KESIMPULAN}

Penelitian yang telah dilakukan, untuk melihat uji daya hambat dan daya bunuh ekstrak buah mengkudu bahwa (Morinda citrifilia Linn) dengan konsentrasi $25 \mathrm{mg} / \mathrm{ml}$, $50 \mathrm{mg} / \mathrm{ml}, 75 \mathrm{mg} / \mathrm{ml}$ dan $100 \mathrm{mg} / \mathrm{ml}$ dapat disimpulkan hasilnya : mampu membunuh bakteri Staphylococcus aureus mulai dari konsentrasi $25 \mathrm{Mg}$, Daya bunuh zona yang kuat terlihat pada konsentrasi $75 \mathrm{mg}$ $100 \mathrm{mg}$, yaitu $>20 \mathrm{~mm}$.

\section{REFERENSI}

Amaliyah, N, D. (2020). Uji Daya Simpan Ekstrak Daun dan Buah Mengkudu 
(Morinda citrifolia.L) terhadap Pertumbuhan Jamur Colletrobricum capsici Asal Cabai Merah secara invitro. Jurnal Pembangunan Pertanian Berkelanjutan dalam perpektif Teknologi, Sosil dan Ekonomi, ISBN 978-6, hal 131-140..

Andri DH, dkk. (2011). Kadar Merkuri Pada Rambut Masyarakat Disekitar Penambang Emas Tanpa ljin. Media Medika Indonesia, 45, 181-187.

Astuti W, dan A. P. (2016). Konsentrasi Efektif Ekstrak Buah Mengkudu ( Morinda citrifolia.L) Terhadap Bakteri Staphylococcus aureus. Jurnal Unswagati Cirebon ( Jurnal Universitas Swadaya Gunung Jati),.

Bhore, S. J., \& Sathisha, G. (2010). Screening of Endophytic Colonizing Bacteria for Cytokinin-Like Compounds : Crude Cell-Free Broth of Endophytic Colonizing Bacteria Is Unsuitable in Cucumber Cotyledon Bioassay. World Journal of Agricultural Sciences, 6(4), 345-352.

Galuh, Puspitasari, D. (2012). No TitleUji Daya Hambat Perasan Buah Mengkudu Matang Terhadap Bakteri Methicillin Resisten Staphylococcus aurens Secara In Vitro. Skripsi, (Kedokteran Hewan:Brawijaya), hal 5.

Hardani, R., Krisna, I. K. A., Hamzah, B., \& Hardani, M. F. (2020). Uji Anti Jamur Ekstrak Buah Mengkudu (Morinda citrifolia L.). Jurnal IPA \& Pembelajaran IPA, 4(1), 92-102. https://doi.org/10.24815/jipi.v4i1.16579

Kelemu, S., Fory, P., Zuleta, C., Ricaurte, J., Rao, I., \& Lascano, C. (2011). Detecting bacterial endophytes in tropical grasses of the Brachiaria genus and determining their role in improving plant growth. African journal of biotechnology, 10(6), 965-976. https://doi.org/10.5897/AJB10.1305

Maizura, M.; Aminah, A.; Wan Aida, W. M. (2011). Total phenolic content and antioxidant activity of kesum (Polygonum minus), ginger (Zingiber officinale) and turmeric (Curcuma longa) extract. International Food Research Journal, 18, 529-534.

Marquez-Santacruz, H. a., HernandezLeon, R., Orozco-Mosqueda, M. C., Velazquez-Sepulveda, I., \& Santoyo,
G. (2010). Diversity of bacterial endophytes in roots of Mexican husk tomato plants (Physalis ixocarpa) and their detection in the rhizosphere. Genetics and molecular research: GMR, 9(4), 2372-2380. https://doi.org/10.4238/vol9-4gmr921

Mj, I., Wmz, W. I., Ahh, N., Z, N. A., Sar, S. S., \& Ga, F. (2011). Anti-proliperative and antioxidant effects of $\mathrm{T}$ inospora crispa (Batawali ). Biomedical Research, 22(1), 57-62.

Ravikumar, S., Inbaneson, S. J., Uthiraselvam, M., Kaleeswari, R., Ramu, A., Banerjee, M. B., \& Rajasekar, J. (2011). Antibacterial Activity of Heterotrophic Endophytes from Karangkadu Mangrove Ecosystem , India. Journal of Pharmacy Research, 4(1), 195-198.

Sadananda, T., Nirupama, R., Chaithra, K., Govindappa, M., Chandrappa, C., \& Raghavendra, V. B. (2011). Antimicrobial and antioxidant activities of endophytes from Tabebuia argentea and identification of anticancer agent (lapachol). J Med Plants ..., 1(16), 1213.ttp://www.researchgate.net/publicati on/235767096_Antimicrobial_and_anti oxidant_activities_of_endophytesfrom Tabebuia_argentea_and_identification _of_anticanceragent_(lapachol)/file/79 e415135be2737f03.pdf

Simatupang, dkk. (2017). Uji Daya Hambat Ekstrak Daun Mengkudu (Morinda citrifolia L) Terhadap Pertumbuhan Candida albicans secara invitro,. jurnal e-GIGI, vol 5(1), Jna-Jun 20.

Yan. (2011). Antagonistic bioactivity of endophytic strains isolated from Salvia miltiorrhiza. African Journal of Biotechnology, 10(67), 15117-15122. https://doi.org/10.5897/AJB11.228

Yan, X., He, L., Song, G., \& Wang, R. (2011). Antagonistic bioactivity of endophytic strains isolated from Salvia miltiorrhiza. 10(67), 15117-15122. https://doi.org/10.5897/AJB11.228

Yang, C., Zhang, X., Shi, G., Zhao, H., Chen, L., Tao, K., \& Hou, T. (2011). Isolation and identification of endophytic bacterium W4 against tomato Botrytis cinerea and antagonistic activity stability. 5(2), 131-136. 